arrangements for attachments to suitable institutions being made by the Indian University Grants Commission. A similar number of visits by Indian scientists to Britain are also provided for, attachments being arranged through the British Council. Nino British scientists have visited India under the scheme since its inauguration and it is hoped to arrange a further six visits during the period April 1, 1966-March 31, 1967. Applications from British scientists, preferably between the ages of 27 and 35, are now invited. Further information and forms of application can be obtained from the Director, Science Department, the British Council, 59 New Oxford Street, London, W.C.1. The closing date for applications is March 15, 1966.

\section{The Paul Instrument Fund Awards}

The Paul Instrument Fund Committee has made grants as follows: $£ 3,250$ to Prof. A. F. Gibson, professor of physics in the University of Essex, for the development of devices to extend the application of infra-red lasers; $£ 700$ to Dr. E. T. Hall, director of the Research Laboratory for Archaeology and History of Art, Oxford, for the construction of a geophysical magnetic simulator; $£ 5,000$ to Mr. A. R. Luxmoore, of the Engineering Department, University College, Swansea, for the construction of a 'Moiré-scope' - a special optical instrument sensitive only to the deformations of a body, and not affected by any rigid body movements (closely comparable with the conventional polariscopes used in photo-elastic measurements of stress). The Paul Instrument Fund Committee, composed of representatives of the Royal Society, the Institute of Physics and the Physical Society and the Institution of Electrical Enginoers, was set up in 1945 "to receive applications from British subjects who are research workers in Great Britain for grants for the design, construction and maintenance of novel, unusual or much-improved types of physical instruments and apparatus for investigations in pure or applied physical science".

\section{Council for National Academic Awards :}

\section{Degree Courses}

Statement No. 3 from the Council for National Academic Awards deals with the approval of courses in science, technology, arts and social studies, leading to the award of the honours or ordinary degrees of B.Sc. or B.A. (Council for National Academic Awards. Statement No. 3. November 1965. Pp. 15 London: Council for National Academic Awards, 1965). For this purpose the Council has established two Boards of Studies: the Committee for Science and Technology, and the Committee for Arts and Social Studies. The Statement deals with the admission of students to courses, the duration and content of courses including training in sandwich courses, with teaching and with examination arrangements. Students who successfully complete honours courses will be granted degrees in four elasses: first-class honours; secondclass honours (first and second divisions); and thirdclass honours.

\section{University of Newcastle upon Tyne : \\ Vice-Chancellor's Report}

The Vice-Chancellor's report to the Court and Council of the University of Newcastle upon Tyno for the poriod August 1, 1964 July 31, 1965, is accompanied by departmental reports and lists of publications, arranged under dopartments (Pp. 152. Newcastle upon Tyne: The University, 1965. n.p.). It records 3,996 undergraduate and 587 postgraduate students; 1,554 students entered in October 1965, compared with 8,702 applications, making a total of 628 postgraduate and 4,247 undergraduate students. Deep concern is expressed over the erosion of the value of recurrent grants in the present quinquennium.
A grant from the Department of Scientific and Industrial Research enabled the University to establish the first centre in Britain for retrieving information on medical science. A university grant enabled members of the University to participate in the 1965 Fezzan Expedition, while the Exploration Society sent an expedition to Afghanistan and undergraduate expeditions to Ioeland and to Greece.

\section{Announcements}

Dr. J. E. Richey, formerly district geologist, H.M. Geological Survey, Scotland, has been awarded the Neill Prize for the period 1963-65 by the Council of the Royal Society of Edinburgh, in recognition of his investigations on the structure of the tertiary volcanoes of Scotland and Northern Ireland.

Mr. W. T. Cooper has been appointed national chairman of the Institute of Fucl, Australian Membership, in succession to Prof. N. Y. Kirov.

The Deutsche Akademie der Naturforscher, Leopoldina has announced the appointment of the following new members: Prof. E. Hasche (Bad Berka); Prof. E. Lesky (Vienna); Prof. H. von Mayersbach (Nijmegen); Prof. H. Merxmuller (Munich); Prof. K. W. Merz (Freiburg).

A COURSE on "Information on a Shoe-string" will be held by ASLIB on March 17. Further information can be obtained from the Education Officer, ASLIB, 3 Belgrave Square, London, S.W.1.

A CONFERENCE on "Stresses in Service", under the auspices of the Joint British Committee for Stress Analysis, will be hold at the Institution of Civil Engineers during March 23-25. Further information can be obtained from the Secretary of the Conference, Institution of Civil Engineers, Great George Street, London, S.W.1.

A ONE-DAY meeting of the Biological Group of ASLIB to discuss the problem of training for university students, rosearch workers and librarians in the biological field will be held at the Northampton Colloge of Advanced Technology on March 25. Further information can be obtained from Miss P. I. Edwards, Department of Botany, British Museum (Natural History), Cromwell Road, London, S.W.7.

A symposium on "Potatoes for the Food Processing Industries", sponsored jointly by the Fruit and Vegetable Preservation Research Association and the Department of Food Science and Technology of the Borough Polytechnic, will be held at the Borough Polytechnic on March 17. Further information can be obtained from Dr. D. B. Smith, Department of Food Science and Technology, Borough Polytechnic, London, S.E.1.

A COURSE of six evening lectures on "The Mechanical and Metallurgical Aspects of Metal Forming" will be held at the Bradford Institute of 'I'echnology on Wednesdays during February 23-March 30. The programme will include: introductory metallurgical principles; crystal structures and imperfections; application of dislocation theory; introduction to the theory of plasticity; mechanics of metal deformation. Further information can be obtained from the Registrar, Bradford Institute of Technology, Bradford 7.

A CONFERENCE on "Electronic Processes in Low Mobility Solids", sponsored jointly by the Departments of Physics and Glass Technology of the University of Sheffield, will be held in the University during April 18-20. The purpose of the meeting is to discuss transport phenomena, optical, dielectric and other properties associatod with electron (or polaron) hopping and tunnelling in solids in which normal band theory may not be applicable. Further information can be obtained from Dr. A. F. Owen, Department of Glass Technology, The University, Northumberland Road, Sheffield 10. 